\title{
CRYSTAL STRUCTURES OF BIS(TRIPHENYLPHOSPHINE OXIDE)TRIBUTYLTIN AND BIS(TRIPHENYLARSINE OXIDE)TRIBUTYLTIN TETRAPHENYLBORATES
}

\author{
Kong Mun Lo', Abdul Razak Ibrahim, Suchada Chantrapromma ${ }^{2,2}$, Hoong-Kun Fun? \\ and Seik Weng $\mathrm{Ng}^{* 3}$ \\ 'Department of Chemistry, University of Malaya, 50603 Kuala Lumpur, Malaysia \\ ${ }^{2}$ X-ray Crystallography Unit, Universiti Sains Malaysia, 11800 Penang, Malaysia \\ ${ }^{3}$ Department of Chemistry, Prince of Songkla University, Hat Yai, Songkla 90112, Thailand \\ ${ }^{4}$ Institute of Postgraduate Studies, University of Malaya, 50603 Kuala Lumpur, Malaysia
}

\begin{abstract}
The tin atom in the cationic complexes, bis(triphenyltin oxide)tributyltin tetraphenylborate and bis(triphenylarsine oxide)tributyltin tetraphenylborate, shows trans- $\mathrm{C}_{3} \mathrm{SnO}_{2}$ trigonal bipyramidal coordination. The O-Sn-O skeleton is linear in the two compounds; however, whereas the $\mathrm{Sn} \leftarrow \mathrm{O}=\mathrm{P}$ entities are approximately linear in the phosphine oxide complex, the $\mathrm{Sn} \leftarrow \mathrm{O}=\mathrm{As}$ units in the arsine oxide complex are bent.
\end{abstract}

\section{Introduction}

The literature on organotin compounds lists only a small number of cationic complexes compared with the much larger number of anionic complexes, the examples being largely limited to those complexes whose positive charge at tin is balanced by the tetraphenylborate counterion. The mesylimide anion, $\left[\left(\mathrm{CH}_{3} \mathrm{SO}_{2}\right)_{2} \mathrm{~N}\right]^{\circ}$, is also able to stabilize the organotin cation [1] as is this anion, like the tetraphenylborate anion, has limited Lewis basicity. Additionally, the organotin cation must be stabilized by neutral donor ligands. The water ligand can only stabilize the cation to a small extent by hydrogen bonding; the water molecules in the diaquatributyltin cation are readily replaced by stronger Lewis bases [2]. Among the cationic organotin complexes, the triorganotin system takes advantage of the increased aqueous solubility arising from the separation of charges [3] for possible biocidal applications. Crystallographic evidence on cationic organotin complexes is sparse; in the unit cell of bis(triphenylarsine oxide)( $p$-chlorophenyl)diphenyltin tetraphenylborate [4], the cations and anions were packed such that there are no interactions between the species. The two title compounds constitute additions to the structural literature on such complexes.

\section{Experimental}

Bis(triphenylphosphine oxide)tributyltin tetraphenylborate was obtained by reacting tributyltin chloride, triphenylphosphine oxide and sodium tetraphenylborate in a 1:2:1 stoichiometry in ethanol. Sodium chloride was formed when the solutions of the reagents were mixed together. Water was added in drops to dissolve the sodium chloride; the cationic complex was forced out of solution by the addition of more water [3]. The solid material was collected and then thoroughly dried by contact with filter paper. The pure compound (1) was obtained by using ethanol as the solvent for crystallization. The triphenylarsine oxide analog (2) was prepared in an identical manner.

Room-temperature diffraction measurements for the crystals of the compounds were carried out on a Siemens CCD area-detector diffractometer $(\lambda=0.71073 \AA)$. The structures were solved by direct methods [5] and were refined on $F^{2}$ [6]. Both structures are disordered in the butyl chains, and a number of restraints were used to treat the disorder. In (2), each butyl chain was disordered as two half-occupancy chains sharing a common $\mathrm{C}_{\mathrm{a}}$-atom. As the disorder affect the other part of the molecule, phenyl rings were refined as rigid hexagons. The structures of the cations are shown as ORTEP [7] plots. For (1), the absolute structure parameter refined to a value close to zero, which enabled the absolute structure [8] to be assigned. Crystal data and refinement values for both compounds are listed in Table 1. 


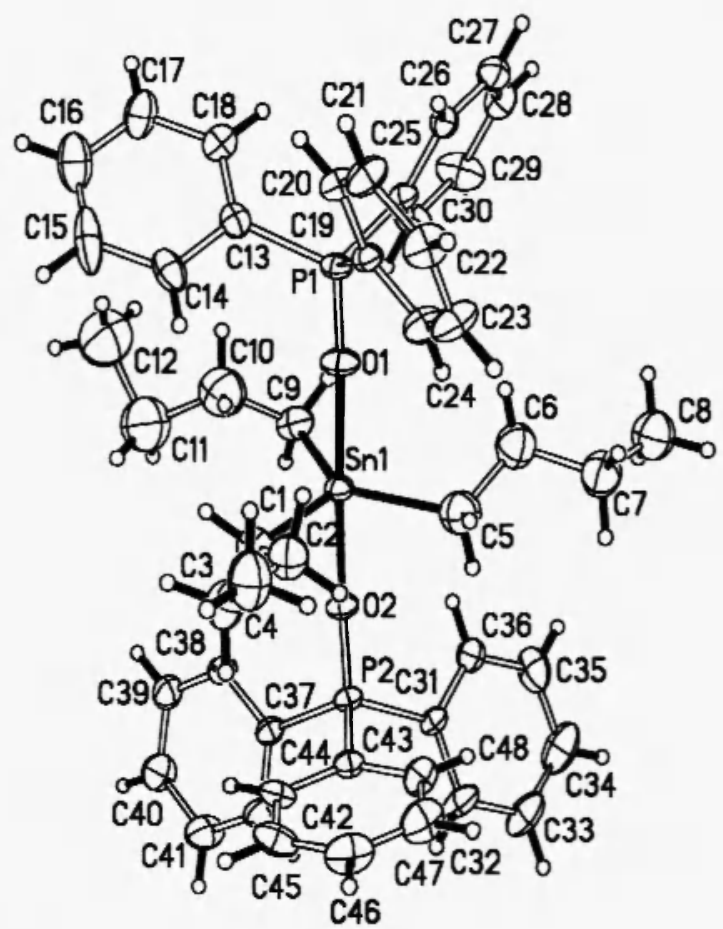

Figure 1. ORTEP plot of the bis(triphenylphosphine oxide)tributyltin cation of (1) at the $10 \%$ probability level. Selected bond distances and angles: $\mathrm{Snl}-\mathrm{Cl}=2.11(1), \mathrm{Sn} 1-\mathrm{C} 5=2.11(1), \mathrm{Sn} 1-\mathrm{C} 9=2.19(1)$, Sn1-O1 $=2.249(6)$, $\mathrm{Sn} 1-\mathrm{O} 2=2.278(5), \mathrm{P} 1-\mathrm{O} 1=1.501(6), \mathrm{P} 2-\mathrm{O} 2=1.486(5)$ A; C1-Sn1-C5 = 116.8(5), C1-Sn1-C9 = 118.4(5), C1$\mathrm{Sn1}-\mathrm{O} 1=90.8(4), \mathrm{Cl}-\mathrm{Sn} 1-\mathrm{O} 2=92.2(4), \mathrm{C} 5-\mathrm{Sn} 1-\mathrm{C} 9=124.4(6), \mathrm{C} 5-\mathrm{Sn} 1-\mathrm{O} 1=92.6(5), \mathrm{C} 5-\mathrm{Sn} 1-\mathrm{O} 2=86.1(5), \mathrm{C} 9-$ $\mathrm{Sn} 1-\mathrm{O} 1=92.8(4), \mathrm{C} 9-\mathrm{Sn} 1-\mathrm{O} 2=85.7(4), \mathrm{O} 1-\mathrm{Sn} 1-\mathrm{O} 2=177.0(2), \mathrm{P} 1-\mathrm{O} 1-\mathrm{Sn} 1=167.4(4), \mathrm{P} 2-\mathrm{O} 2-\mathrm{Sn} 1=152.5(4)^{\circ}$.

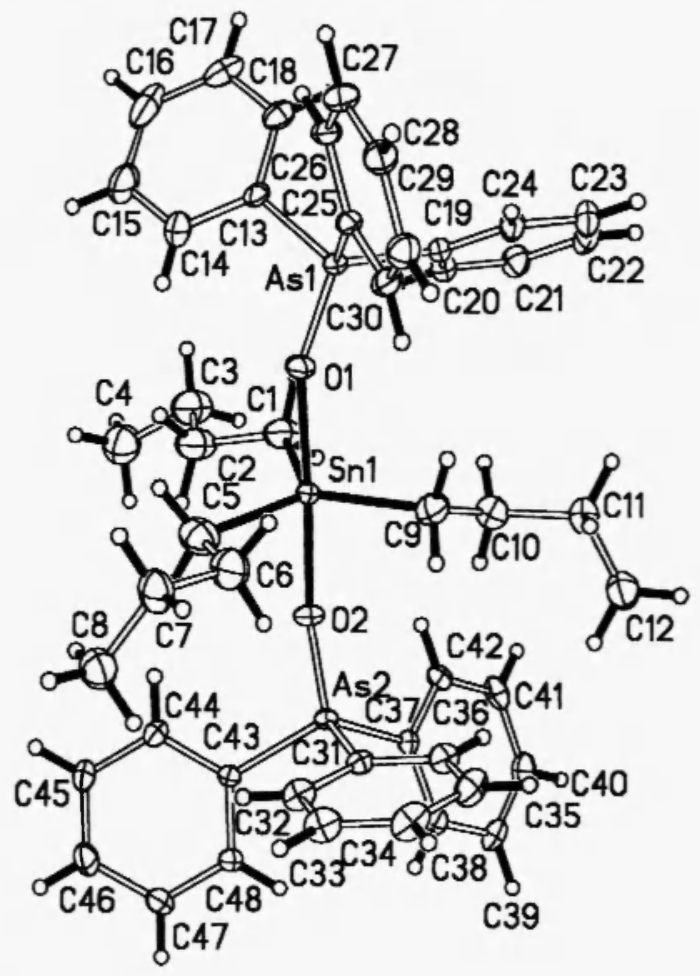

Figure 2. ORTEP plot of the bis(triphenylarsine oxide)tributyltin cation of (2) at the $30 \%$ probability level. Selected bond distances and angles: Snl-Cl $=2.155(8), \mathrm{Sn} 1-\mathrm{C} 5=2.151(9)$, Snl-C9 $=2.147(8)$, Sn1-O1 $=$ 2.238(4), $\mathrm{Snl}-\mathrm{O} 2=2.254(4), \mathrm{As} 1-\mathrm{O} 1=1.653(4), \mathrm{As} 2-\mathrm{O} 2=1.663(3) \mathrm{A} ; \mathrm{Cl} 1 \mathrm{Sn} 1-\mathrm{C} 5=116.0(4), \mathrm{Cl}-\mathrm{Sn} 1-\mathrm{C} 9=$ 123.3(3), $\mathrm{C} 1-\mathrm{Snl}-\mathrm{Ol}=93.1(3), \mathrm{C} 1-\mathrm{Sn} 1-\mathrm{O} 2=86.2(3), \mathrm{C} 9-\mathrm{Sn} 1-\mathrm{O} 1=88.1(2), \mathrm{C} 5-\mathrm{Sn} 1-\mathrm{C} 9=120.7(4), \mathrm{C} 5-\mathrm{Sn} 1-\mathrm{O} 1=$ 86.6(3), C5-Sn1-O2 = 91.2(3), C9-Sn1-O2 = 94.5(2), O1-Sn1-O2 = 177.2(2), As1-O1-Sn 1 = 144.0(3), As2-O2$\mathrm{Sn} 1=144.6(2)^{\circ}$. 
Table 1. Crystal and refinement data for (1) and (2)

\begin{tabular}{|c|c|c|}
\hline & 1 & 2 \\
\hline Empirical formula & $\mathrm{C}_{72} \mathrm{H}_{77} \mathrm{BO}_{2} \mathrm{P}_{2} \mathrm{Sn}$ & $\mathrm{C}_{72} \mathrm{H}_{77} \mathrm{As}_{2} \mathrm{BO}_{2} \mathrm{Sn}$ \\
\hline Formula weight & 1165.78 & 1253.68 \\
\hline Crystal system, space group & Orthorhombic, Pna2 & Triclinic, $P-1$ \\
\hline Cell dimensions $a \AA, \alpha^{\circ}$ & 19.3888(2), & 11.2273(3), \\
\hline$b \AA, \beta^{\circ}$ & 15.1486(3), & 14.7650(3), \\
\hline$c \AA, \gamma^{\circ}$ & $\begin{array}{l}22.171(1) \\
6511.9(2)\end{array}$ & $\begin{array}{l}21.4819(5) \\
3293.7(1)\end{array}$ \\
\hline$Z$ & 4 & 2 \\
\hline Calculated density, $\mathrm{g} \mathrm{cm}^{-3}$ & 1.189 & 1.264 \\
\hline Absorption coefficient, $\mathrm{mm}^{-1}$ & 0.484 & 1.427 \\
\hline$F(000)$ & 2440 & 1292 \\
\hline Crystal size, mm & $0.48 \times 0.42 \times 0.40$ & $0.46 \times 0.40 \times 0.28$ \\
\hline$\theta$ range of data, ${ }^{\circ}$ & 1.63 to 25.00 & 1.01 to 25.00 \\
\hline $\begin{array}{l}\text { Limiting indices, } \pm h, \pm k, \pm l \\
\text { Reflections collected / unique }\end{array}$ & $\begin{array}{l}-22 \text { to } 23,-15 \text { to } 18,-26 \text { to } 24 \\
35029 / 11247\left(R_{\text {int }}=0.090\right)\end{array}$ & $\begin{array}{l}-13 \text { to } 10,-16 \text { to } 17,-25 \text { to } 25 \\
18855 / 11394\left(\mathrm{R}_{\mathrm{int}}=0.059\right)\end{array}$ \\
\hline Completeness to $\theta=25^{\circ}$ & $100.0 \%$ & $98.2 \%$ \\
\hline $\begin{array}{l}\text { Max. and min. transmission } \\
\text { Restraints / parameters }\end{array}$ & $\begin{array}{l}0.830 \text { to } 0.801 \\
142 / 584\end{array}$ & $\begin{array}{l}0.691 \text { to } 0.560 \\
156 / 610\end{array}$ \\
\hline $\begin{array}{l}\text { Goodness-of-fit on } F^{2} \\
\text { Weighting scheme }\end{array}$ & $\begin{array}{l}0.935 \\
{\left[\sigma^{2}+(0.1067 P)^{2}\right]^{-1}}\end{array}$ & 0.981 \\
\hline $\begin{array}{l}\text { Weighting scheme, } w \\
\text { Reflections with } I>2 \sigma(I)\end{array}$ & $\begin{array}{l}{\left[\sigma^{-}+(0.1067 P)^{\prime}\right]} \\
6190\end{array}$ & $\begin{array}{l}{\left[\sigma+(0.0687 P)^{2}\right]} \\
7569\end{array}$ \\
\hline Final $R$ indices $[l>2 \sigma(l)]$ & $R_{1}=0.063, w R_{2}=0.159$ & $R_{1}=0.058, w R_{2}=0.147$ \\
\hline$R$ indices (all data) & $R_{1}=0.116, w R_{2}=0.191$ & $R_{1}=0.083, w R_{2}=0.160$ \\
\hline Absolute structure parameter & $-0.05(3)$ & \\
\hline Extinction coefficient & $0.0020(3)$ & $0.0020(3)$ \\
\hline Largest diff. peak and hole, $e \AA^{-3}$ & 0.47 to -0.46 & 0.69 to -0.99 \\
\hline CCDC deposition number & 162188 & 168189 \\
\hline
\end{tabular}

\section{Results and Discussion}

The bis(triphenylphosphine oxide)tributyltin (Figure 1) and bis(triphenlarsine oxide)tributyltin (Figure 2) cations have their five-coordinate metal atoms in a trans- $\mathrm{C}_{3} \mathrm{SnO}_{2}$ trigonal bipyramidal geometry; this coordination geometry was suggested from tin-119m Mössbauer spectroscopic measurements [2]. In the bis(triphenyphosphine oxide)tributyltin cation, the tin atom is displaced by $0.078(8) \AA$ out of the trigonal plane in the direction of the $\mathrm{Ol}$ atom, which forms a marginally shorter bond than the $\mathrm{O} 2$ atom, i.e., the phosphine-oxide ligand bearing the $\mathrm{Ol}$ atom appears to be more Lewis basic than the ligand bearing the $\mathrm{O} 2$ atom as implied by the less bent $\mathrm{Sn} \leftarrow \mathrm{O}=\mathrm{P}$ skeleton. The unusually large $\mathrm{Sn} \leftarrow \mathrm{O}=\mathrm{P}$ angle is a typical feature of organotin complexes of phosphine oxides, and there are more than 140 examples in the structural literature that have the $\mathrm{C}-\mathrm{Sn} \leftarrow \mathrm{O}=\mathrm{P}$ fragment [9]. In contrast, the angles at the oxygen atom in carbonyl [10] and amine-oxide [11] donor complexes are much smaller, these being close to the $120^{\circ}$ angle expected for $s p^{2}$-hybridized oxygen. In the triphenylarsine oxide complex, the tin atom is displaced out of the trigonal plane by $0.027(5) \AA$, in the direction of the $\mathrm{O} 2$ atom. The bond distances and angles of the two triphenylarsine oxide ligands are similar. The tin-oxygen distances are not significantly different from each other in the two cations, and the greater Lewis basicity of the arsine oxide donor compared with the phosphine oxide donor has only a minor effect on these bond dimensions $\left(\mathrm{Sn} \leftarrow \mathrm{O}_{\mathrm{P}}=2.249(6), 2.278(5) \AA ; \mathrm{Sn} \leftarrow \mathrm{O}_{\mathrm{As}}=2.238(4)\right.$,

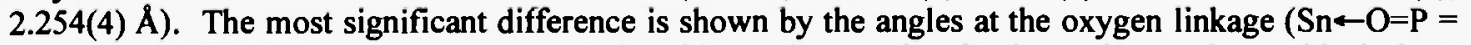
$\left.152.5(4), 167.4(4)^{\circ}\right)$ in the phosphine oxide adduct whereas that in the arsine analog oxide is bent $\left(\mathrm{Sn} \leftarrow \mathrm{O}=\mathrm{As}=144.0(3), 144.6(2)^{\circ}\right)$.

In both compounds, the tetrahedral tetraphenylborate anions do not interact with the cations. Because of the size of the cation and anion, both compounds do not pack well. The triclinic cell has 4 voids totaling $89.8 \AA^{3}$ and the orthorhombic cell 8 voids totaling $146.2 \AA^{3}$. However, the voids are not large enough to accommodate water molecules.

Several complexes of triorganotin derivatives with the same phosphine oxide and arsine oxide ligands have been authenticated crystallographically; the 2:1 triphenyltin coumarin-3-carboxylate adducts of triphenylphosphine and triphenylarsine oxides are isomorphous $(\mathrm{Sn} \leftarrow \mathrm{O}=\mathrm{P}=166.4(2)$, $\left.\mathrm{Sn} \leftarrow \mathrm{O}=\mathrm{As}=159.4(2)^{\circ}\right)[12]$, the pair having matching cell dimensions. On the other hand, the triphenyltin nitrate complex of the same donors are not isomorphous, the phosphine oxide complex crystallizing in a centrosymmetric space group $\left(\mathrm{Sn} \leftarrow \mathrm{O}=\mathrm{P}=153(1)^{\circ}\right)$ and the arsine oxide 
$\left(\mathrm{Sn} \leftarrow \mathrm{O}=\mathrm{As}=136.0(3)^{\circ}\right)$ in a non-centric space group [13]. The 2:1 triphenyltin chloride adduct with 1,2-bis(diphenylphosphinyl)ethane $\left(\mathrm{Sn} \leftarrow \mathrm{O}=\mathrm{P}=161.8(2)^{\circ}\right)$ and 1,2-bis(diphenylarsoryl)ethane $\left(\mathrm{Sn} \leftarrow \mathrm{O}=\mathrm{As}=134.5(2)^{\circ}\right)$ differ significantly in the coordination environment of the metal atom [14]. In these comparison structures, the angle is larger in the phosphine oxide complex.

In chloroform solution, both compounds retain their five-coordinate status, as noted from the one-bond coupling constants [ $\delta$ (coupling constant) $=21.4\left({ }^{1} J\left|\mathrm{Sn}-\mathrm{C}_{1}\right|=461.4\right), 27.7\left({ }^{2} J\left|\mathrm{Sn}-\mathrm{C}_{2}\right|=27.8\right)$, $26.6\left({ }^{2} J\left|\mathrm{Sn}-\mathrm{C}_{3}\right|=79.4 \mathrm{~Hz}\right), 13.1 \mathrm{ppm}$ for the triphenylphosphine oxide adduct; $\delta$ (coupling constant) $=$

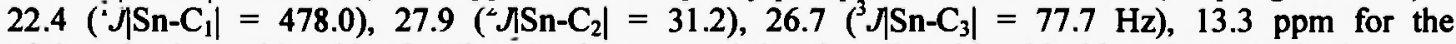
triphenylarsine oxide adduct]. The ${ }^{i} J$. values exceed that for tributyltin chloride $(339.5 \mathrm{~Hz})$ in the same solvent, but are comparable with the values for tributyltin chloride dissolved in the donor solvents, dimethylsulfoxide and hexamethylphosphoramide [15]; when dissolved in the solvents, the Lewis acid is assumed to be coordinated by the donor molecules.

\section{Acknowledgments}

We thank the National Science Council for R \& D, Malaysia (IRPA 305/PFIZIK/610961) and the University of Malaya (F0758/2001A) for supporting this work.

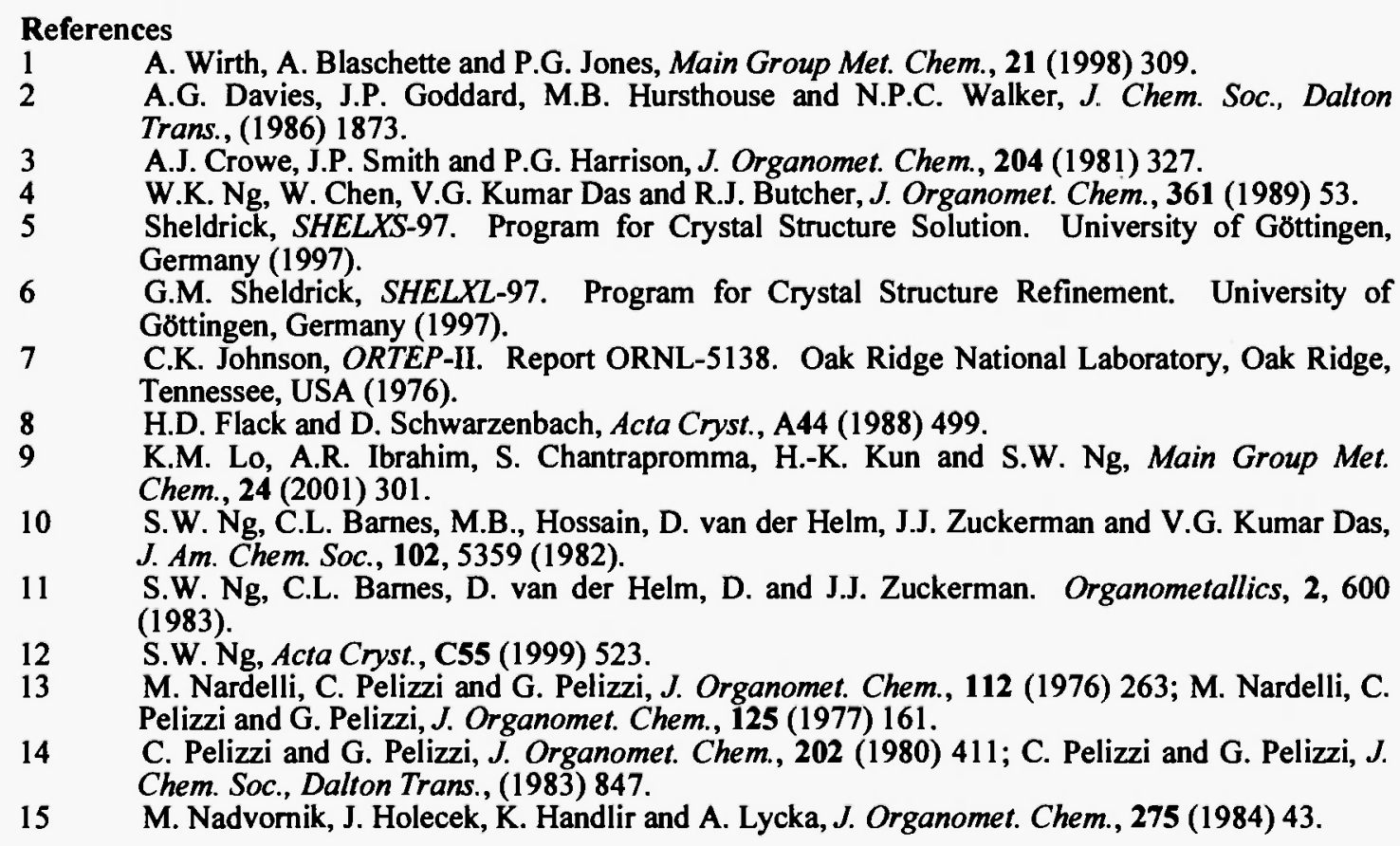

Recelved: Aprll 20, 2001 - Accepted: Aprll 27, 2001 Accepted in publishable format: May 17, 2001 